\title{
Impact of beak manipulation on egg production, some hematological and physiological parameters of Japanese quail raised under Upper Egypt climatic conditions
}

Ahmed Abdel-kareem Abuoghaba ( $\nabla$ abuoghaba@yahoo.com )

Sohag University Faculty of Agriculture

Dina Abdel-Fattah Selim

Menoufia University

Mostafa Galal Abdelfattah

Assiut University Faculty of Agriculture

\section{Research Article}

Keywords: Beak trimming, Egg production, Japanese quail, hematological and physiological estimates

Posted Date: July 14th, 2021

DOl: https://doi.org/10.21203/rs.3.rs-707527/v1

License: (1) (i) This work is licensed under a Creative Commons Attribution 4.0 International License.

Read Full License 


\section{Abstract}

Impact of beak manipulation on egg production, some hematological and physiological parameters of Japanese quail raised under Upper Egypt climatic conditions

\section{Introduction}

The poultry industry specialists that the phenomenon of predation caused large economic losses, and resulting in reducing the productive efficacy of quails. It was, therefore, necessary to find solutions to overcome this problem and the consequent losses, and these suggestions were followed by cutting the beak to the birds at an early age (Pizzolante et al., 2006; Bennett et al., 2016). In general, raising Japanese quail under high intensity, especially during the breeding period, there are aggressive reactions among birds such as cannibalism and embossed feathers (Cloutier et al., 2000). Beak trimming for different birds is performed as a strategy to minimize peck injuries (Pizzolante at al., 2007), feather pecking, and mortality (Guesdon et al., 2006; Ribe and Hinrichsen 2017) especially for laying hens, turkeys, and quails (Gentle et al., 1995; Glatz, 2004; Khalil et al., 2015).

The beak of the birds is a functional organ supply with an extensive nerve, therefore, there are several anatomical and physiological as well as some biochemical changes, which occur in both cut peripheral nerves as well as damaged tissues after beak trimming (Kuenzel 2007). Beak trimming for the birds is the removal of approximately one-quarter (Sandilands and Savory 2002) to one-third of the upper beak (Glatz 2004) or both upper and lower beak (Van Liere 1995) of a bird. Traditionally, four methods have been used to beak trimming as mechanical, electrical, hot-blade as well as infra-red. However, using other approaches as lasers, chemical retardation as well as freeze-drying, but these methods are not used in widespread (Glatz, 2004). The beak trimming in various birds is significantly affected by numerous factors such as light intensity, environmental temperature, and type of poultry house as well as flock density and the genetic lines (Hughes and Gentle 1995). The better flock uniformity and lower feed waste and consequently good feathering, and the author recommends two trimmings in the pullet phase for quail's beak trimmed at 12 days as well as from 30 to 35 days of age (Oliveira 2002). Beak trimming is considered a stressful procedure that leads to a reduction of cannibalism and feather pecking, egg pecking as well as broken eggs. Thus, due to the little information on the optimal trimming method, which necessary to obtained good results, this experiment aimed to compares the effect of beak trimming and cauterizing on the performance, egg quality, and hatchability of Japanese quail.

\section{Materials And Methods}

The research was carried out at the Experimental Poultry Farm, Faculty of Agriculture, Assiut University, Egypt.

\section{Experimental design and quail's treatments}


A total number of 288 Japanese quails, 6 weeks old, with average initial body weight (254 and $269 \mathrm{~g})$ for male and female, respectively ( 3 groups $\times 8$ replicates $\times 12$ birds) with $1 \mathrm{M}: 2 \mathrm{~F}$ sex ratio were raised under normal managerial and hygienic conditions on litter pens in the rearing house, and then they transferred to the pens with diminutions ( $57 \mathrm{~cm}$ width $\times 40 \mathrm{~cm}$ length $\times 30 \mathrm{~cm}$ height). In the first group, quails were kept without any treatment and considered as the untrimmed group (UTB). The quails in the second group were trimming at $1 / 3$ of the beak length (TB) by using LYON beak trimmer, USA, while the quails in the third group were cauterizing at $1 / 3$ of the beak length (CB). All male and female quails were trimmed and cauterized at 15 days of age and then re-trimmed and re-cauterized at 56 days of age. Each pen was equipped with a stainless nipple drinker and a trough plastic feeder, which was located at the pen front. They were raised under normal environmental conditions $\left(20-28^{\circ} \mathrm{C}\right.$ temperature and $60-65 \%$ humidity) and exposed daily to 16 continuous lighting hours. All quails were fed ad-libitum on a basal diet containing $21 \%$ crude protein and $3050 \mathrm{Kcal} \mathrm{ME} / \mathrm{kg}$ diet.

\section{Studied traits}

\section{Productive traits}

The birds were weighed at the bingeing ( 8 weeks of age) and the end (24 weeks of age) of the experiment. The eggs were weighed and recorded daily, while feed consumption was measured weekly. Egg mass was calculated by multiplying the egg numbers and egg weight. The feed conversion ratio (FCR) was calculated by dividing feed consumption by egg mass.

\section{Incubation traits}

Eight hundred and forty fresh eggs were used to determine the fertility and hatchability percentages at two times of incubation, in the first one, 420 eggs ( 140 eggs $\times 3$ groups), while those in $2^{\text {nd }}$ time 420 eggs (140 eggs $\times 3$ groups) were incubated at 18 and 20 weeks of age, respectively. All eggs were collected during five consecutive days and then stored at $18^{\circ} \mathrm{C}$ and $65 \%$ relative humidity $(\mathrm{RH})$ before placing them in the incubator. All incubated eggs were weighed and numbered prior to placing them in the incubator, then they were exposed to the incubator conditions; $37.8^{\circ} \mathrm{C}$ with $55-60 \% \mathrm{RH}$ up to 14 days of the incubation period, while the $\mathrm{RH}$ from 15-17days of incubation was 60 to $65 \%$. On hatch time, the live and dead chicks were counted, while the un-hatched eggs were opened to classify either as infertile or the embryonic mortality (Khalil et al., 2015).

The hatchability of set eggs (\%) was calculated by dividing the number of hatched eggs and the number of hatched eggs $\times 100$, while the hatchability of fertile eggs (\%) was calculated by dividing the number of hatched eggs by the number of fertile eggs $\times 100$. Embryonic mortality $(\%)$ was calculated by dividing the number of dead embryos to all viable eggs at transfer $\times 100$ (Ayaşan 2013).

\section{Egg quality traits}


A total of 120 fresh eggs from all experimental groups (three groups $\times$ eight replicates $\times$ five eggs) were used to determine the egg quality traits (egg weight, shape index, yolk index, Haugh unit, shell thickness, and egg component percentages) at 16 weeks of age. The electronic caliper was used to determine both egg length and width, while shape index, yolk index, shell percentage, and Haugh unite were estimated (Carter 1995; Kul and Seker 2004):

- Shape index $=$ egg width $(\mathrm{cm}) /$ egg height $(\mathrm{cm}) \times 100$

- Yolk index $=$ yolk height $(\mathrm{cm}) /$ yolk diameter $(\mathrm{cm}) \times 100$

- Shell percentage $=$ Shell weight $(g) /$ Egg weight $(\mathrm{g}) \times 100$

Haugh unit $(H U)=100 \log \left(H+7.57-1.7 W^{0.37}\right)$, where the $H=$ thick albumen height, while $W=$ egg weight.

\section{Injuries responses}

A distance scoring system which is an effective and easy method was used for determining the feathers damage (Bright et al., 2006; Lambton et al., 2013): Three areas on the body (neck, back, and rump) were scored from 0 (good feathered or very little damage) to 4 (feathers severe damage, several naked areas and/or broken skin). Also, the tail and wing feathers were scored from 0 (normal feathers) to 4 (total feathers missing or broken and/or bleeding from the fragile skin). The quails were randomly chosen to determine plumage quality by counting 5 quails to the left, thus the feather-scoring that fifth quail in the slatted, litter as well as range areas. From each area, 10 quails were scored to estimate plumage quality, and then 2 quails were examined to assess both the vent and cannibalism scores. The flock prevalence of feather pecking in different groups was calculated as a percentage of quails with damaged feathers from the total quails scored.

\section{Hematological parameters}

At 16 weeks of age, 48 blood samples ( 24 males and 24 females) i.e. sixteen quails ( 8 males and 8 females) per each group for were randomly collected from the brachial vein into heparinized tubes to determine the blood cells (Gross and Siegel 1983). The Wright's stain was used to stain the smears. The granular and non-granular of the one hundred leucocytes cells microscopic fields were counted, while a ratio of the $\mathrm{H} / \mathrm{L}$ was calculated. The plasma was obtained by centrifugation at $4000 \mathrm{~g}$ for $15 \mathrm{~min}$ and then stored at $-20^{\circ} \mathrm{C}$ up to analysis. The testosterone hormone concentrations were determined by using a testosterone enzyme immunoassay test kit (Biocheck, Inc. 323 Vintage Park Drive, Foster City, CA 94404). The absorbance was measured using a microplate reader within 15 minutes (Biotek ELX 808 IU) set at a wavelength of $450 \mathrm{~nm}$. The hemoglobin concentration $(\mathrm{g} / 100 \mathrm{~mL})$ and hematocrit value $(\%)$ were measured according to the Drew et al., 2004 method.

\section{Statistical analysis}


The collected data were subjected to a one-way analysis of variance with the beak trimming effect by using the GLM procedure of SAS User's Guide (SAS 2004). The significant differences between different treatments were determined by using Duncan's new multiple ranges test (Duncan 1955).

\section{Results And Discussions}

\section{Egg production, feed intake and feed conversion ratio}

The performance of laying quails in the UTB, TB and CB groups are presented in table 1. The findings showed that the means of final body weight, egg numbers, and egg production of treated quails were significantly $(p<0.05)$ greater in comparison with control, while the means of egg weight were not affected. Also, the obtained findings indicated that the egg mass for treated quails was significantly heavier $(p<0.05)$ than that of the quails in the control group. The improved body weight and egg production for quails in the TB and CB groups could be attributed to improved feed efficiency, as well as lower mortality and pecked egg incidence, which reflects the less aggressive behavior. Also, the improved body weight may be due to better feed efficiency in quails, which are not able to select feed ingredients and consequently preventing feed wastage (Pizzolante et al., 2007). These results agreed with Kuo et al., [1991], who found that the egg production rate and mass of bird's beak-trimmed at one-half of the upper beak at 4 weeks of age were significantly improved than those of beak-trimmed one-quarter of the upper beak and control birds. These results disagree with Pizzolante et al., (2007) found that the lower egg production for Japanese quails exposed to severe beak trimming (1/2) compared to that not beaktrimmed as well as $1 / 3$ beak trimmed.

Also, the obtained findings indicated that the egg mass for treated quails was significantly heavier $(p<0.05)$ than that of the quails in the control group. This increase could be attributed to improving egg number and feed intake resulting in a lower feed conversion ratio as compared with the control. Similarly, the lower egg mass was recorded of quails trimmed the beak at $1 / 2$ of the beak length compared with the quails not beak-trimmed and $1 / 3$ of the beak trimmed (Pizzolante et al., 2007). Also, the findings of Hassanien and Abdel-Wareth (2015) showed that the egg weight for hens in the beak trimmed and the non-trimmed beak was not affected.

In this study, the results indicated that the feed intake in the TB and CB groups was significantly $(p \leq 0.001)$ decreased than that of the UTB, while the feed conversion ratio was significantly $(p<0.05)$ increased (Table 1). In Table 2, It's reported that the changes in the feed intake after beak trimming in the quails could be attributed to decreased feed motivation, which reflected the increase in the pain presence, as well as discomfort caused by the tissue, nerve, and sensory receptors damage (Gentle 1995). The findings in Table 1 agreed with those of Blokhuis et al., (1987), who stated that the beak trimming improved feed conversion due to less feed waste. Also, the lower feed intake was recorded in the infrared beak treatment group, followed by a hot blade beak trimming group, while the lowest one $(P<0.05)$ was recorded of control birds up to 9 weeks post-treatment (Marchant-Forde and Cheng 2010). In contrast, the worse feed conversion ratio was recorded in quails trimmed and cauterized at $1 / 3$ and $2 / 3$ of the beak 
than that of the control (non-trimmed) birds (Leandro et al., 2005). Similarly, Maızama and Adams (1994) reported that FCR was better for layers in the untrimmed group than trimmed groups during the period from 20 to 40 weeks of age.

Results in figure 1 indicated that the mortality rate for both males and females in the UTB quails was remarkably higher than those of the TB and CB groups. The effect of beak trimming and beak cauterizing on the mortality rate are shown in figure 1 . Results of present study indicated that the mortality rate for both males and females in the UTB quails was remarkably higher than those of the TB and CB groups. The increased mortality rate in the UTB quails could be attributed to high aggressive behavior among males, which leads to increased injury responses in the different areas, cannibalism, and consequently increased mortality rate. These results agree with those of Oliveira (2002), who found that the better performance as well as the lower mortality rate for de-beaked quails than those of quails submitted to poor beak trimming practices. Similarly, using the beak trimming of quails especially at 14 or 21 days to improving the performance as well as reducing the mortality rate (Pizzolante et al., 2007).

\section{Hatchability, fertility and embryonic mortality rates}

The percentages of hatchability of set eggs, hatchability of fertile eggs, fertility, piped eggs and embryonic mortality of laying quails in treated and untreated groups are presented in table 3 . The results indicated that the hatchability of fertile eggs percentage for chicks produced from quails in the TB and CB groups decreased significantly $(p<0.05)$ than that of quails produced from quails in the UTB group, while the percentages of hatchability of set eggs and piped eggs were not influenced. The obtained results in table 3 indicated that the highest fertility percentage was recorded of the quails in the TB group, while the lowest percentages were in the UTB and CB groups.

These findings indicated that the early and late embryonic mortalities for chick embryos produced from quails in the TB and CB groups were significantly $(p \leq 0.01)$ influenced, while the percentages of embryonic mortalities during mid-period and malposition percentages were not affected than that of the UTB.

The results in Table 2, indicated that the hatchability of fertile eggs percentage for chicks produced from quails in the TB and CB groups decreased significantly $(p<0.05)$ than that of quails produced from quails in the UTB group, while the percentages of hatchability of set eggs and piped eggs were not influenced. The highest fertility percentage was recorded of the quails in the TB group, while the lowest percentages were in the UTB and CB groups. The obtained results agree with those of Khalil et al., (2012), who found that the fertility and hatchability percentages were improved in the debeaked Japanese quail group than those of the control sand and straw groups, respectively. The different embryonic mortalities could be attributed to the adverse effect of aggressive responses of quails in the UTB, which increased cannibalism and consequently decreased the viability of embryos (Chang et al., 2009). Similarly, no significant effect on the egg weight and shape index for eggs produced from non-trimmed laying hens at one, 10 days and 10 weeks of age (Onbaşılar et al., 2009). 


\section{Egg quality traits}

Egg weight and egg shape index were not affected by the trimming of the beak (Table 3). The means of egg yolk index in the UTB and TB groups were significantly greater than the CB group. The means of Haugh units for eggs produced from quails in the TB and CB groups were significantly lower than that of the quails in the UTB group. Shell thickness was significantly higher for the cauterized quails group compared to the TB group $(p<0.01)$. The highest yolk percentage was recorded at $32.54 \%$ for the quails in the CB group, followed by $31.81 \%$ in the TB group, while the lowest one was obtained for the quails in the UTB group. The highest percentage of albumen was recorded $59.51 \%$ for the quails in the UTB, followed by $59.34 \%$ in the TB quails, while the lowest one was obtained in the CB group. The shell percentage of eggs produced from quails in the CB group significantly $(p \leq 0.01)$ increased than those of the UTB and TB groups. The obtained findings agreed with those of Hassanien and Abdel-Wareth (2012), who found that the percentages of shell and yolk were significantly higher in the trimming hens, while the albumen percentage was significantly lower than that of the birds in the control group. Also, they found that the Haugh unit was not affected by trimming beak groups. Similarly, the high percentage of fertility and hatchability were recorded for eggs produced from the quails in the control and debeaked groups, while the low fertility percentage was obtained in eggs produced from quails in the sand and straw groups (Khalil et al., 2015).

\section{Feather plumage (injuries responses) of Japanese quails}

The feather scores for different body regions of the male and female quails are presented in table 4 . The feather score of the neck, rump, back, tail, and wing was significantly $(p<0.001)$ differed in the different groups. The feather score of the neck, rump, back, tail, and wing were significantly $(p<0.001)$ differed in the different groups. Generally, the injury responses could be attributed to several reasons as aggressive behavior between males, the frequency copulation behavior of the males, and force copulations for males with unreceptive females [Stephanie et al., 2011; Yamauchi et al., 2017], which decreased in the treated quails compared with quails in the control group. These results agreed with Bilcik and Keeling (1999) who found a correlation between the area pecked frequently and the body parts or feather structures, which can be easily touched as the back and tail of birds. Also, the total feather score in the birds housed in furnished cages at different body parts significantly $(p<0.05)$ increased during the period from 25 to 29 (beak trimming) weeks of age (Shinmura et al., 2006). They stated that the increments of neck, breast, and tail feather scores were smaller for the birds in the furnished cages.

\section{Hematological parameters}

In female quails, the WBC and hemoglobin concentration, as well as lymphocyte cells, were significantly $(P<0.05)$ higher in the TB and CB groups. The RBC was not affected by beak trimming and cauterizing (Table 5). Regarding the effect of beak trimming on the male quails hematological parameters, the results in table 6 indicated that the white blood cell counts in the treated groups were significantly increased than that of the control. The means of hemoglobin and RBC were not affected by the trimming and cauterizing of the beak in quails. The H/L ratio in the TB and CB quails was significantly $(P<0.05)$ decreased since 
the highest values were obtained in the UTB, while the lowest was recorded in the treated groups. In female quails, the higher lymphocyte percentage could be reflecting the better immunity response of quails, while increased heterophils percentage refers to the adverse effect of beak trimming (Abdelfattah 2018). The means of hemoglobin and RBC were not affected by the trimming and cauterizing of the beak in quails. The $H / L$ ratio in the TB and CB quails was significantly $(P<0.05)$ decreased since the highest values were obtained in the UTB, while the lowest was recorded in the treated groups. Similarly, the the $H / L$ ratio was increased in the birds under stressful conditions (Gross and Siegel 1983). As known, the $\mathrm{H} / \mathrm{L}$ ratio in the quails was used as an index to measure different stress for birds (Mahmoud et al. 2013). These increased WBCs, heterophils and $\mathrm{H} / \mathrm{L}$ ratio could reflect the adverse effects of aggressive effects on lymphoid organs weights, which significantly reduced by crowding and aggression stressors of quails. Also, this may be due to the reduction in feed consumption, which providing fewer nutrients for this organ development (Bartlett and Smith, 2003).

\section{Testosterone hormone concentration of male Japanese quails}

Regarding the effect of beak trimming and cauterizing on the testosterone hormone concentration of male quails (figure 2), the obtained results indicated that testosterone hormone concentrations in the TB and CB groups were significantly decreased than that of the quails in the UTB group.

The decreased testosterone hormone in the treated quails could be attributed to reducing aggressive behavior effects especially between males and females (Delville et al., 1984; Hauet al., 2004), which lead to improving fed consumption, viability, and consequently egg production and egg mass. These results are in harmony with Wingfield et al., (1990) who reported that the testosterone hormone concentration of male quails plays an important role in Japanese quail's behavior, which reached maximum level during the breeding season. Similarly, the highest concentration of serum testosterone was recorded in males Japanese quail raised in the straw group, while the lowest concentrations were recorded in debeaked and sand groups (Khalil et al., 2015).

\section{Conclusion}

Based on these findings on the present experiment, it could be concluded that using trimming and cauterizing at $1 / 3$ of the beak length had positive effects on productive traits and physiological estimates for male and female Japanese quails, in order to reduced testosterone hormone resulting in minimize aggressive behavior and feather picking. Also, trimming and cauterizing of the beak for quails significantly improved feed utilization by reducing feed waste.

\section{Declarations}

\section{Author contribution}

Conceptualization: A. A. Abuoghaba and M. G. Abdelfattah; methodology: A. A. Abuoghaba and M. G. Abdelfattah; statistical analysis: A. A. Abuoghaba; data collection: A. A. Abuoghaba, and M. G. 
Abdelfattah; write (original draft preparation): A. A. Abuoghaba, Dina A. Selim and M. G. Abdelfattah; writing (review and editing): A. A. Abuoghaba, Dina A. Selim and M. G. Abdelfattah; supervision: A. A. Abuoghaba, Dina A. Selim and M. G. Abdelfattah

Funding This work was not financially supported by the Assiut University, but was self-financed at our own expense.

Data availability Data will be made available on reasonable request.

Code availability Data were analyzed using SAS (9.1).

\section{Declarations}

Ethics approval All the procedures used in this study have been approved by the Institutional Animal Ethics Committee (IAEC) of Assiut University, Egypt.

\section{Conflict of interest}

The authors declare that no conflict of interest.

\section{Acknowledgments}

This study was performed at Experimental Poultry Farm, Poultry production Department, Faculty of Agriculture, Assiut University, Assiut, Egypt.

\section{References}

Abdelfattah, M, G., 2018. Physiological and productive impacts of beak trimming and feed form in Japanese quail. Egyptian J. Anim. Prod. 55: 171-185.

https://pdfs.semanticscholar.org/1856/db9fe0e2ee5b91a4c0930f5d274b36b76ffb.pdf

Ayaşan, T., 2013. Effects of dietary inclusion of protexin (probiotic) on hatchability of Japanese quails. Indian J. Anim. Sci. 83: 78-81. www.researchgate.net/publication/287696519

Bartlett, J.R., Smith, M.O., 2003. Effects of different levels of zinc on the performance and immunocompetence of broilers under heat stress. Poult. Sci. 82: 1580-

1588. https://doi.org/10.1093/ps/82.10.1580.

Bennett, R.M., Jones, P.J., Nicol, C.J., Tranter, R.B., Weeks, C.A., 2016. Consumer attitudes to injurious pecking in free range egg production. Anim. Welfare. 25: 91-100.

https://doi.org/10.7120/09627286.25.1.091

Blokhuis. H.J., Van der Haar, J.W., Koole, P.G., 1987. Effects of beak trimming and floor type on feed consumption and body weight of pullets during rearing. Poult. Sci. 66: 623-625.

https://doi.org/10.3382/ps.0660623 
Bilcik, B., Keeling, L.J., 1999. Change in feather condition in relation to feather pecking and aggressive behaviour in laying hens. British J. Poult. Sci. 40: 444-451. https://doi.org/10.1080/00071669987188

Bright, A., Jones, T.A., Dawkins, M.S., 2006. A non-intrusive method of assessing plumage condition in commercial flocks of laying hens. Animal Welfare. 15: 113-118.

https://www.ingentaconnect.com/contentone/ufaw/aw/2006/00000015/00000002/art00003

Carter, T.C., 1975. The hen's egg: a rapid method for routine estimation of flock means shell thickness. British Poult. Sci. 16: 131-143. doi.org/10.1080/00071667508416171

Chang, G.B., Liu, X.P., Chang, H., Chen, G.H., Zhao, W.M., Ji, D.J., Chen, R., Qin, Y.R., Shi, X.K., Hu, G.S., 2009. Behavior differentiation between wild Japanese quail, domestic quail, and their first filial generation. Poult. Sci. 88: 1137-1142. https://doi.org/10.3382/ps.2008-00320

Cloutier, S., Newberry, R.C., Forster, C.T., Girsberger, K.M., 2000. Does pecking at inanimate stimuli predict cannibalistic behavior in domestic fowl. Applied Anim. Behavior Sci. 66: 119-133.

https://doi.org/10.1016/S0168-1591(99)00068-4

Delville, Y., Sulon, J., Hendrick, J.C., Balthazart, J., 1984. Effect of the presence of females on the pituitarytesticular activity in male Japanese quail (Coturnix coturnix japonica). General and Comparative Endocrinology. 55: 295-305. http://hdl.handle.net/2268/162750

Drew, P., Harles, C.R.J.S., Trevor, B., John, L., 2004. Oxford Handbook of Clinical Hematology. ${ }^{\text {th }}$ Edition, Oxford University Press, USA. https://oxfordmedicine.com/view/10.1093/med/9780199683307.001.0001/med-978019968 3307

Duncan, D.B., 1955. Multiple range and multiple $F$ testes. Biometrics. 11: 1-42.

Glatz. P., 2004. Laser beak-trimming: a report for the Australian Egg Corporation Limited. July, AECL Publication No 04/05. https://www.australianeggs.org.au/for-farmers/

Gentle, M.J., Thorp, B.H., Hughes, B.O., 1995. Anatomical consequences of partial beak amputation (beak trimming) in turkeys. Res Vet Sci. 58: 158-162. https://doi.org/10.1016/0034-5288(95)90070-5

Gross, W.B., Siegel, P.B., 1983. Evaluation of the heterophil/lymphocyte ratio as a measure of stress in chickens. Avian Diseases. 27: 972-979. doi.org/10.2307/1590198

Guesdon, V., Ahmed, A.M.H., Mallet, S., 2006. Effects of beak trimming and cage design on laying hen performance and egg quality. British Poult. Sci. 47: 1-12. https://doi.org/10.1080/ 00071660500468124

Hassanien, H.H.M., Abdel-Wareth, A.A.A., 2012. Influence of beak trimming and stocking density on performance and egg quality of laying hens in a tropical environment. Egyptian J. Anim. Prod. 49: 45-51. https://search.emarefa.net/detail/BIM-346843 
Hau, M., Dominguez, O.A., Evrard, H.C., 2004. Testosterone reduces responsiveness to nociceptive stimuli in a wild bird. Hormones and Behavior. 46: 165-170. https://doi.org/10.1016/j.yhbeh.2004.02.007 _

Hughes, B.O., 1995. Gentle MJ. Beak trimming of poultry: its implications for welfare. World's Poult. Sci. 51: 51-61. doi.org/10.1079/WPS199050005

Khalil, H.A., Hanafy, A.M., Mekawy, Aml. I., Mady, M.E., 2015. Effect of males pecking behavior on productive and physiological performance of Japanese quail and using some ways to reduce this behavior. Egyptian Poult. Sci. 35: 857-873. http://www.epsaegypt.com

Kuenzel, W.J., 2007. Neurobiological basis of sensory perception: Welfare implications of beak trimming. Poult. Sci. 86: 1273-1282. https://doi.org/10.1093/ps/86.6.1273

Kul, S., Seker, I., 2004. Phenotypic Correlations Between Some External and Internal Egg Quality Traits in the Japanese Quail (Coturnix coturnix japonica). International J. Poult. Sci. 3: 400-405. doi.org/10.3923/ijps.2004.400.405

Kuo, F.L., Craig, J.V., Muir, W.M., 1991. Selection and beak-trimming effects on behaviour, cannibalism, and short-term production traits in White Leghorn pullets. Poult. Sci. 70: 1057. https://doi.org/10.3382/ps.0701057

Lambton, S.L., Nicol, C.J., Friel, M., Main, D.C., McKinstry, J.L., Sherwin, C.M., Walton, J., Weeks, C.A., 2013. A bespoke management package can reduce levels of injurious pecking in loose-housed laying hen flocks. Veterinary Res. 172: 423-428. doi.org/10.1136/vr.101067

Leandro, N.S.M., Vieira, N.S., Matos, M,S., Café, M.B., Stringhini, J.H., Santos, D.A.,2005. Desempenho produtivo de codornasjaponesas (Coturnixcoturnix japonica) submetidas a diferentesdensidades e tipos de debicagem. Acta Scientiarum Anim Sci. 27: 129-135.

https://doi.org/10.4025/actascianimsci.v27i1.1263

Mahmoud, U.T., Abdel-Rahman, M.A., Darwish, M.H.A., Mosaad, G.M., 2013. The Effect of Heat Stress on Blood Picture of Japanese Quail. J. Advance Vet Res. 3; 69-76.

https://advetresearch.com/index.php/AVR/article/view/118/117

Maızama, D.G., Adams, A.W., 1994. Effect of beak trimming, blade temperature and age at beak trimming on performance of two strains of egg layers. J. Appl. Poult. Res. 3: 69-73.

https://doi.org/10.1093/japr/3.1.69

Marchant-Forde, R.M., Cheng, H.W., 2010. Different effects of infrared and one-half hot blade beak trimming on beak topography and growth. Poult. Sci. 89: 2559-2564. https://doi.org/10.3382/ps.201000890

Oliveira, B.L., 2002. Manejo racional e produtividade das codornas (Coturnix coturnix japônica). In: Simpósio Internacional De Coturnicultura, 01, Lavras. Anais. Lavras: UFLA, 77-84. 
Onbaşılar, E.E., Demirtaş, Ş.E., Kahraman, Z., Karademir, E., Demir, S., 2009. The influence of different beak trimming age on performance, $\mathrm{H}-\mathrm{L}$ ratio and antibody production to SRBC in laying hens. Trop Anim. Health Prod. 41: 221-227. doi.org/10.1007/s11250-008-9179-5

Pizzolante, C.C., Garcia, E.A., Saldanha, E.A.P.B., Laganá, C., Batista. L., Deodato, Ap., Souza. A.L.P., 2006. Beak-Trimming Methods and their Effect on the Performance of Japanese Quail Pullets (Coturnix japonica). Brazilian J. Poult. Sci. 8: 213-216. https://doi.org/10.1590/S1516-635X2006000400002

Pizzolante, C.C., Garcia, E.A., Saldanha, E.S.P.B., Langana, C., Faitarona, A.B.G., Souza, H.B.A., Pelicia, K., 2007. Beak trimming methods and their effects of the performance and egg quality of Japanese quails during lay. Brazilian J. Poult. Sci. 6:17-21. https://doi.org/10.1590/S1516-635X2007000100003

Riber, A.B., Hinrichsen, L.K., 2017. Welfare consequences of omitting beak trimming in laying hens. Frontiers in Vet Sci. 4: 222. https://doi.org/10.3389/fvets.2017.00222

SAS, Institute. SAS/STAT user's guide. 2004, Version 9.1. SAS Institute Inc., Cary, NC.

Sandilands, V., Savory, C.J., 2002. Ontogeny of behaviour in intact and beak trimmed layer pullets, with special reference to preening. British Poult. Sci. 43: 182-189.

https://doi.org/10.1080/00071660120121373

Shinmura, T., Eguchi, Y., Uetake, K., Tanaka, T., 2006. Effects of light intensity and beak trimming on preventing aggression in laying hens. Anim Sci J. 77: 447-453. doi: 10.1111/j.1740-0929.2006.00371.x

Stephanie, M.C., Horan, C.M., Johnson, P.A., Adkins-Regan, E., 2013. Copulatory behaviors and body condition predict post-mating female hormone concentrations, fertilization success, and primary sex ratios in Japanese quail. Hormones and Behavior. 59: 556-564. doi.org/10.1016/j.yhbeh.2011.02.009

Van Liere, D.W., 1995. Responsiveness to a novel preening stimulus long after partial beak amputation (beak trimming) in laying hens. Behavior Processes. 34: 169-174. https://doi.org/10.1016/03766357(94)00066-P

Wingfield, J.C., Hegner, R.E., Dufty, A.M., Ball, G.F., 1990. The "challenge hypothesis": theoretical implications for patterns of testosterone secretion, mating systems, and breeding strategies. The American Naturalist. 136: 829-846. https://doi.org/10.1086/285134

Yamauchi, Y., Yoshida, S., Matsuyama, H., Obi, T., Takase, K., 2017. Morphologically abnormal beaks observed in chickens that were beak-trimmed at young ages. J. Vet Med Sci. 79: 1466-1471. doi.org/10.1292/jvms.17-0287

\section{Tables}

Table 1 Impact of beak manipulation on the egg production, feed intake and feed conversion ratio of Japanese quails 


\begin{tabular}{llllll} 
& \multicolumn{2}{l}{ Beak manipulation } & \multicolumn{2}{c}{ SEM } & P-Value \\
\cline { 2 - 4 } & $1^{\text {st }}(\mathrm{UTB})$ & $2^{\text {nd }}(\mathrm{TB})$ & $3^{\text {rd }}(\mathrm{CB})$ & & \\
\hline Initial body weight & 269.97 & 269.88 & 269.97 & 3.52 & 0.9998 \\
\hline Final body weight & $259.69^{\mathrm{b}}$ & $280.77^{\mathrm{a}}$ & $271.96^{\mathrm{a}}$ & 3.38 & 0.0002 \\
\hline Average egg number (no.) & $4.16^{\mathrm{b}}$ & $5.20^{\mathrm{a}}$ & $5.42^{\mathrm{a}}$ & 0.27 & 0.0119 \\
\hline Total egg number & $16.63^{\mathrm{b}}$ & $20.80^{\mathrm{a}}$ & $21.69^{\mathrm{a}}$ & 0.94 & 0.0023 \\
\hline Egg production (\%) & $67.77^{\mathrm{b}}$ & $74.71^{\mathrm{a}}$ & $74.34^{\mathrm{a}}$ & 1.91 & 0.0298 \\
\hline Egg weight (g) & 12.15 & 12.32 & 12.22 & 0.06 & 0.2329 \\
\hline Egg mass (g egg/hen) & $8.25^{\mathrm{b}}$ & $9.21^{\mathrm{a}}$ & $9.08^{\mathrm{a}}$ & 0.24 & 0.0232 \\
\hline Total egg mass (g egg/hen) & $32.99^{\mathrm{b}}$ & $36.84^{\mathrm{a}}$ & $36.32^{\mathrm{a}}$ & 1.17 & 0.0374 \\
\hline Daily feed intake (g/bird/day) & $37.35^{\mathrm{a}}$ & $32.20^{\mathrm{b}}$ & $31.01^{\mathrm{b}}$ & 0.83 & 0.0001 \\
\hline Feed conversion ratio (g feed/g egg) & $3.09^{\mathrm{a}}$ & $2.62^{\mathrm{b}}$ & $2.55^{\mathrm{b}}$ & 0.06 & 0.0001
\end{tabular}

$A, b$ Means followed by different lowercase letters in the same row are significantly different $(P \leq 0.05)$. $\mathrm{SEM}=$ standard error of the mean. UTB=Un-trimming beak group, $\mathrm{TB}=$ trimming beak, $\mathrm{CB}=$ cauterizing beak

Table 2 Impact of beak manipulation on the hatchability, fertility and embryonic mortality of Japanese quails 


\begin{tabular}{|c|c|c|c|c|c|c|}
\hline \multirow{2}{*}{\multicolumn{2}{|c|}{ Parameters }} & \multicolumn{3}{|c|}{ Beak manipulation } & \multirow[t]{2}{*}{ SEM } & \multirow[t]{2}{*}{ P-Value } \\
\hline & & $1^{\text {st }}($ UTB $)$ & $2^{\text {nd }}(T B)$ & $3^{\text {rd }}(\mathrm{CB})$ & & \\
\hline \multicolumn{2}{|c|}{ Hatchability of set eggs (\%) } & 71.49 & 67.86 & 67.61 & 1.52 & 0.3446 \\
\hline \multicolumn{2}{|c|}{ Hatchability of fertile eggs (\%) } & $63.87^{\mathrm{a}}$ & $57.70^{\mathrm{b}}$ & $56.27^{\mathrm{b}}$ & 1.32 & 0.0219 \\
\hline \multicolumn{2}{|l|}{ Fertility (\%) } & $83.69^{b}$ & $89.31^{a}$ & $84.97^{b}$ & 1.16 & 0.0474 \\
\hline \multicolumn{2}{|l|}{ Piped eggs (\%) } & 2.58 & 2.99 & 1.53 & 0.63 & 0.3769 \\
\hline \multirow[t]{4}{*}{ Embryonic mortality (\%) } & Early 0-7 days & $10.22^{\mathrm{a}}$ & $7.02^{b}$ & $9.59^{\mathrm{ab}}$ & 1.23 & 0.0444 \\
\hline & Mid 7-14 days & 3.99 & 3.15 & 2.86 & 0.74 & 0.2594 \\
\hline & Late14-18 days & $16.91^{\mathrm{ab}}$ & $19.91^{\mathrm{a}}$ & $14.09^{b}$ & 1.15 & 0.0042 \\
\hline & Malposition & 33.07 & 33.07 & 28.70 & 33.1 & 0.0960 \\
\hline
\end{tabular}

$A, b$ Means followed by different lowercase letters in the same row are significantly different $(P \leq 0.05)$. $\mathrm{SEM}=$ standard error of the mean. UTB=Untrimmed beak group, $\mathrm{TB}=$ trimmed beak, $\mathrm{CB}=$ cauterized beak

Table 3 Impact of beak manipulation on the egg quality traits of Japanese quails

\begin{tabular}{|llllll|}
\hline Parameters & \multicolumn{3}{c}{ Beak manipulation } & \multicolumn{3}{c|}{ SEM } & P-Value \\
\cline { 2 - 5 } & $1^{\text {st }}(\mathrm{UTB})$ & $2^{\text {nd }}(\mathrm{TB})$ & $3^{\text {rd }}(\mathrm{CB})$ & & \\
\cline { 1 - 5 } Egg weight (g) & 12.32 & 12.42 & 12.82 & 0.17 & 0.1014 \\
\hline Egg shape index (\%) & 79.72 & 77.99 & 79.02 & 1.29 & 0.6378 \\
\hline Egg yolk index (\%) & $47.14^{\mathrm{a}}$ & $47.34^{\mathrm{a}}$ & $43.34^{\mathrm{b}}$ & 0.62 & 0.0001 \\
\hline Haugh units & $91.98^{\mathrm{a}}$ & $89.26^{\mathrm{b}}$ & $88.00^{\mathrm{b}}$ & 0.59 & 0.0001 \\
\hline Shell thickness (mm) & $22.38^{\mathrm{ab}}$ & $22.08^{\mathrm{b}}$ & $22.93^{\mathrm{a}}$ & 0.27 & 0.0531 \\
\hline Yolk (\%) & $31.52^{\mathrm{b}}$ & $31.81^{\mathrm{ab}}$ & $32.54^{\mathrm{a}}$ & 0.27 & 0.0265 \\
\hline Albumen (\%) & $59.51^{\mathrm{a}}$ & $59.34^{\mathrm{a}}$ & $58.16^{\mathrm{b}}$ & 0.29 & 0.0027 \\
\hline Shell (\%) & $8.97^{\mathrm{b}}$ & $8.85^{\mathrm{b}}$ & $9.29^{\mathrm{a}}$ & 0.10 & 0.0094 \\
\hline
\end{tabular}

$A, b$ Means followed by different lowercase letters in the same row are significantly different $(P \leq 0.05)$. $\mathrm{SEM}=$ standard error of the mean. UTB=Un-trimming beak group, $\mathrm{TB}=$ trimming beak, $\mathrm{CB}=$ cauterizing beak 
Table 4 Impact of beak manipulation on injuries responses of male and female Japanese quails

\begin{tabular}{|c|c|c|c|c|c|c|}
\hline \multirow[t]{2}{*}{ Sex } & \multirow[t]{2}{*}{ Parameters } & \multicolumn{3}{|c|}{ Beak manipulation } & \multirow[t]{2}{*}{ SEM } & \multirow[t]{2}{*}{ P-Value } \\
\hline & & $1^{\text {st }}$ (UTB) & $2^{\text {nd }}(T B)$ & $3^{\text {rd }}(\mathrm{CB})$ & & \\
\hline \multirow[t]{6}{*}{ Males } & Head & $2.41^{\mathrm{a}}$ & $1.75^{b}$ & $1.48^{\mathrm{b}}$ & 0.155 & 0.0001 \\
\hline & Neck & $2.22^{a}$ & $1.66^{b}$ & $1.13^{c}$ & 0.11 & 0.0001 \\
\hline & Back & $2.52^{a}$ & $1.59^{\mathrm{b}}$ & $1.42^{\mathrm{b}}$ & 0.12 & 0.0001 \\
\hline & Wing & $2.41^{\mathrm{a}}$ & $1.41^{b}$ & $1.29^{b}$ & 0.12 & 0.0001 \\
\hline & Tail & $2.15^{\mathrm{a}}$ & $1.16^{\mathrm{b}}$ & $1.39^{b}$ & 0.11 & 0.0001 \\
\hline & Leg & $1.48^{\mathrm{a}}$ & $1.09^{b}$ & $1.06^{\mathrm{b}}$ & 1.13 & 0.0001 \\
\hline \multirow[t]{6}{*}{ Females } & Head & $2.21^{a}$ & $1.35^{\mathrm{b}}$ & $1.43^{\mathrm{b}}$ & 0.09 & 0.0001 \\
\hline & Neck & $2.04^{\mathrm{a}}$ & $1.38^{\mathrm{b}}$ & $1.26^{\mathrm{C}}$ & 0.09 & 0.0001 \\
\hline & Back & $2.85^{\mathrm{a}}$ & $1.97^{\mathrm{b}}$ & $1.72^{b}$ & 0.09 & 0.0001 \\
\hline & Wing & $2.10^{a}$ & $1.35^{\mathrm{b}}$ & $1.22^{\mathrm{b}}$ & 0.08 & 0.0001 \\
\hline & Tail & $2.21^{a}$ & $1.23^{b}$ & $1.16^{b}$ & 0.08 & 0.0001 \\
\hline & Leg & $2.31^{a}$ & $1.30^{b}$ & $1.24^{\mathrm{b}}$ & 1.12 & 0.0001 \\
\hline
\end{tabular}

$A, b$ Means followed by different lowercase letters in the same row are significantly different $(P \leq 0.05)$. $\mathrm{SEM}=$ standard error of mean. UTB=Un-trimming beak group, $\mathrm{TB}=$ trimming beak, $\mathrm{CB}=$ cauterizing beak

Table 5 Impact of beak manipulation on the hematological parameters of Japanese quails 


\begin{tabular}{|c|c|c|c|c|c|c|}
\hline \multirow[t]{2}{*}{ Sex } & \multirow[t]{2}{*}{ Parameters } & \multicolumn{3}{|c|}{ Beak manipulation } & \multirow[t]{2}{*}{ SEM } & \multirow[t]{2}{*}{ P-Value } \\
\hline & & $1^{\text {st }}($ UTB $)$ & $2^{\text {nd }}(\mathrm{TB})$ & $3^{\text {rd }}(\mathrm{CB})$ & & \\
\hline \multirow[t]{4}{*}{ Females } & $\mathrm{RBC}\left(\times 10^{6} / \mu \mathrm{L}\right)$ & 3.10 & 3.55 & 3.31 & 0.257 & 0.4732 \\
\hline & WBC $\left(\times 10^{3} / \mu \mathrm{L}\right)$ & $17.25^{\mathrm{b}}$ & $23.25^{\mathrm{a}}$ & $22.50^{\mathrm{a}}$ & 1.373 & 0.0108 \\
\hline & Hemoglobin $(\mathrm{g} / \mathrm{dL})$ & $11.75^{\mathrm{b}}$ & $14.75^{a}$ & $14.00^{\mathrm{ab}}$ & 0.798 & 0.0383 \\
\hline & $\mathrm{H} / \mathrm{L}$ ratio & $0.41^{\mathrm{a}}$ & $0.30^{\mathrm{b}}$ & $0.30^{\mathrm{b}}$ & 0.016 & 0.0001 \\
\hline \multirow[t]{4}{*}{ Males } & $\mathrm{RBC}\left(\times 10^{6} / \mu \mathrm{L}\right)$ & 3.32 & 3.74 & 3.65 & 0.157 & 0.1667 \\
\hline & WBC $\left(\times 10^{3} / \mu \mathrm{L}\right)$ & $18.00^{\mathrm{b}}$ & $23.25^{\mathrm{a}}$ & $20.25^{\mathrm{ab}}$ & 1.316 & 0.0336 \\
\hline & Hemoglobin $(\mathrm{g} / \mathrm{dL})$ & 12.50 & 15.50 & 13.25 & 1.203 & 0.2102 \\
\hline & $\mathrm{H} / \mathrm{L}$ ratio & $0.39^{a}$ & $0.27^{\mathrm{b}}$ & $0.29^{b}$ & 0.020 & 0.0054 \\
\hline
\end{tabular}

$A, b$ Means followed by different lowercased letters in the same row are significantly different $(P \leq 0.05)$. $\mathrm{SEM}=$ standard error of mean. UTB=Un-trimming beak group, $\mathrm{TB}=$ trimming beak, $\mathrm{CB}=$ cauterizing beak

Figures

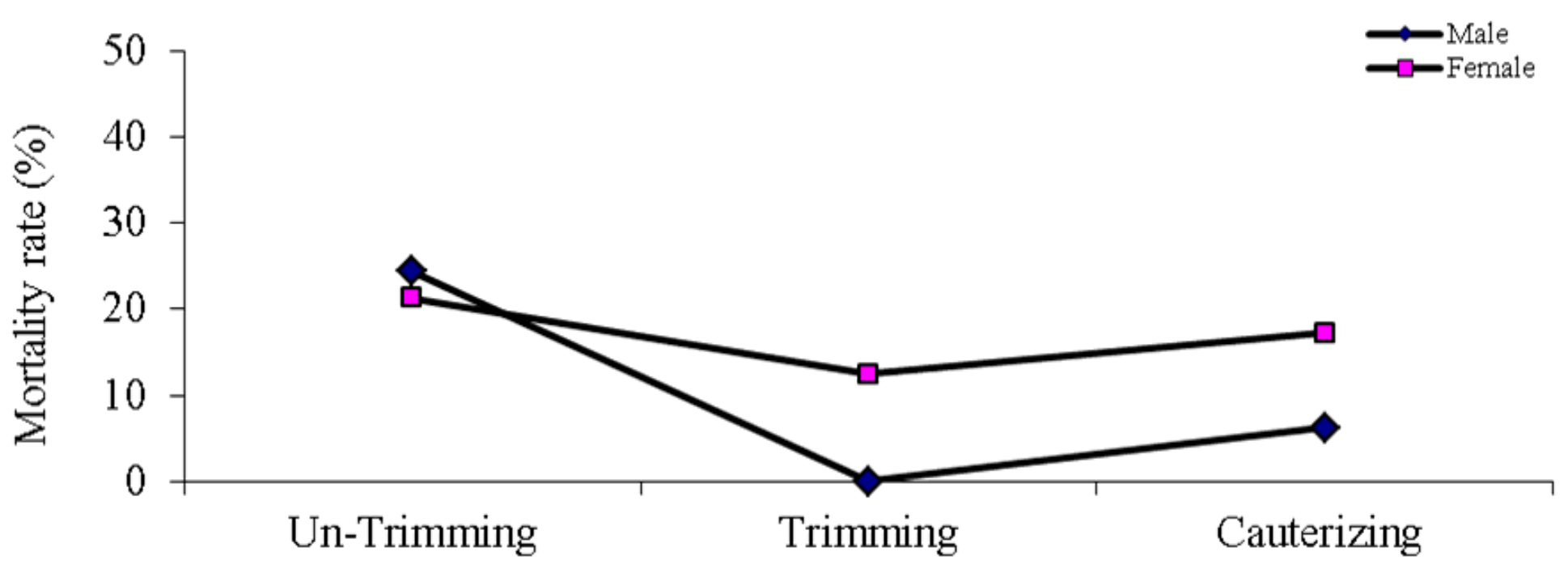

Figure 1

Impact of beak manipulation on mortality rate of male and female Japanese quails 


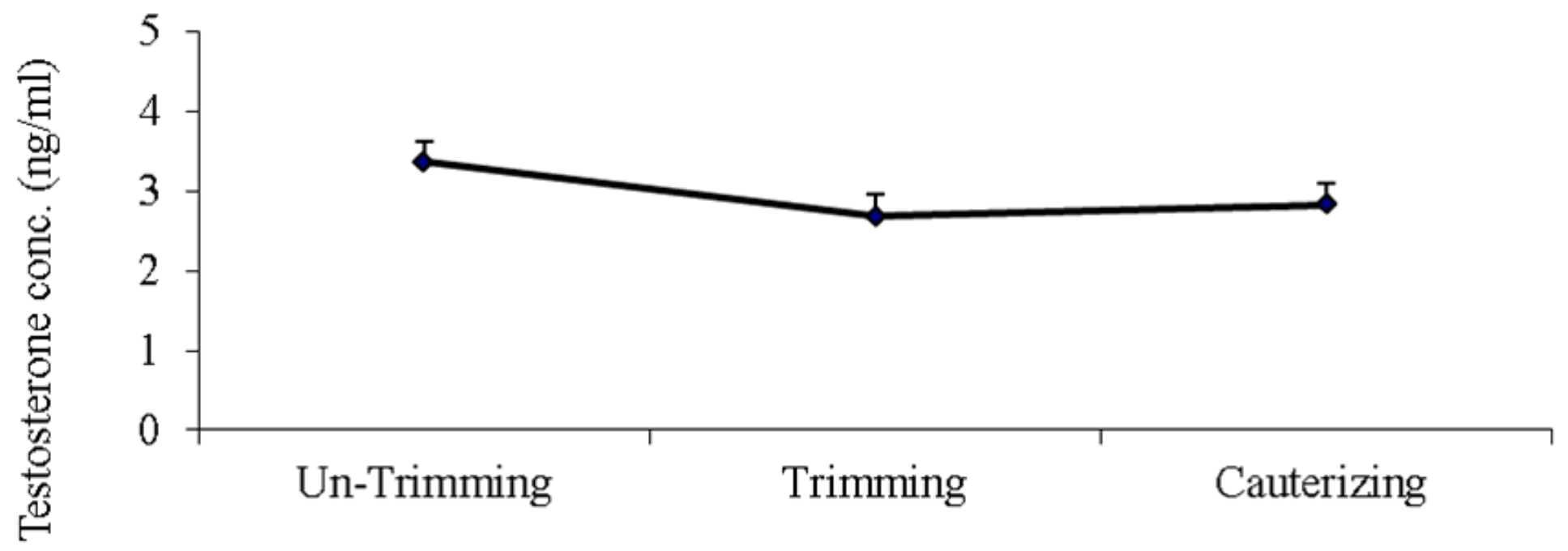

Figure 2

Impact of beak manipulation on testosterone hormone concentration of male Japanese quails 